\title{
8.10 Формування пошуково-дослідницьких умінь майбутніх педагогів: практичний аспект
}

Нова стратегія підготовки майбутніх педагогів зумовлена потребою в формуванні нового покоління вихователів дітей дошкільного віку, вчителів початкових класів, здатних реалізовувати освітні цілі в умовах освітніх трансформацій, навчатися впродовж життя.

Важливість означених положень увиразнюється Професійними стандартами за професіями «Вчитель початкових класів закладу загальної середньої освіти», «Вчитель закладу загальної середньої освіти», «Вчитель початкової освіти (з дипломом молодшого спеціаліста)» (2020) [667], Професійним стандартом «Вихователь закладу дошкільної освіти» (2021) [668], у яких визначено перелік компетентностей та трудових функцій, якими мають володіти педагоги. У зв’язку з цим, пріоритетним у підготовці майбутніх фахівців із дошкільної та початкової освіти $є$ формування їхніх пошуководослідницьких умінь, які складають основу виконання ними трудових дій відповідно до нових освітніх стандартів.

Нині у педагогічній теорії $є$ значний масив джерел, автори яких опосередковано чи безпосередньо розкривають різні аспекти підготовки майбутніх педагогів (В. Андрущенко, О. Антонова, В. Бондар, О. Дубасенюк, Г. Іванюк， В. Огнев’юк， С. Сисоєва， Л. Хомич) в умовах реалізації нової освітньої стратегії. Репрезентативну базу окремих питань, що розглядаються у руслі тематики пропонованого дослідження, складають праці українських науковців. Так, питання підготовки майбутніх педагогів із урахуванням антропологічного, аксіологічного, діяльнісного підходу знайшли втілення у дослідженнях Г. Іванюк [669]. Питання формування у студентів педагогічних спеціальностей пошуково-дослідницьких, рефлексивних умінь, навичок XXI століття як складових їхнього особистісно-професійного розвитку є предметом дослідження Г. Іванюк, Є. Антипіна, О. Венгловської, Л. Куземко, І. Новик [670, с. 5]. Теоретичний інтерес становлять наукові розвідки I. Раєвської, О. Саган, які 
фокусують увагу на формуванні дослідницьких умінь майбутніх учителів початкової школи у перебігу викладання навчальних дисциплін [672]. Вивчення теоретичних напрацювань засвідчило, що попри значний пласт наукових публікацій, окремі питання щодо формування пошуково-дослідницьких умінь майбутніх педагогів у межах реалізації нової стратегії підготовки фахівців залишаються відкритими для наукового пошуку.

Вивчення нормативних документів про освіту, зокрема законів України «Про освіту» (2017), «Про вищу освіту» (2014), Державного стандарту початкової освіти (2019), Державного стандарту дошкільної освіти (Базовий компонент дошкільної освіти), 2021) засвідчило, що заклади дошкільної, загальної середньої освіти (початкова школа) потребують педагога, у якого сформовані здатності та готовність до роботи в умовах освітніх змін, організації розвивальної діяльності здобувачів освіти, що грунтується на врахуванні їхніх запитів і потреб, продукування тих освітніх продуктів, що є затребуваними серед учасників освітнього процесу.

У цьому контексті увиразнюється потреба в залучені здобувачів вищої освіти до пошуково-дослідницької діяльності на різних етапах навчання. Варто зазначити, що освітньо-професійні програми першого (бакалаврського), другого (магістерського) рівнів вищої освіти передбачають різні види пошуководослідницької діяльності студентів.

У пропонованій розвідці зосередимо увагу на особливостях формування пошуково-дослідницьких умінь майбутніх педагогів під час виконання ними магістерських робіт (проєктів). Означений вид пошуково-дослідницької діяльності виконується студентами на завершальному етапі навчання у закладі вищої освіти.

Професорсько-викладацьким складом кафедри педагогіки та психології Київського університету імені Бориса Грінченка напрацьовано значний досвід щодо здійснення педагогічного супроводу виконання майбутніми вихователями дітей дошкільного віку та вчителями початкових класів магістерських проєктів, що спрямовані на розроблення власних освітніх продуктів. 
Варто зазначити, що пошуково-дослідницька діяльність студентів грунтується на особистісній, аксіологічній стратегії, оскільки, як зазначає Г. Іванюк «підготовка педагогів в освітньому процесі закладу вищої освіти насамперед має відповідати суспільним потребам. Однак, варто пам'ятати, що студент є носієм і продуктом цінностей» [673, с. 73]. Відтак, тематика пошуководослідницьких проєктів формується з урахуванням потреб студентів - майбутніх фахівців із дошкільної та початкової освіти, а також запитів педагогів-практиків, оскільки саме вони визначають дієвість і практичну значущість цих проєктів.

У контексті пропонованого дослідження важливо було з'ясувати сутність поняття «пошуково-дослідницькі уміння», охарактеризувати особливості формування досліджуваних умінь на різних етапах роботи над пошуководослідницьким проєктом.

Вивчення різних груп джерел дало можливість 3'ясувати сутність поняття «пошуково-дослідницькі уміння», що у дослідженні розглядаються як комплекс здатностей майбутніх вихователів дітей дошкільного віку та вчителів початкових класів до виконання дій, що пов'язані із умінням визначати освітні цілі та завдання пошуково-дослідницького проєкту, планувати етапи виконання дослідницьких завдань, здійснювати систематизацію та аналіз джерел, пов’язаних із проблематикою дослідження, робити відбір необхідних ресурсів та інструментів, інтерпретувати, узагальнювати, презентувати результати дослідницького пошуку.

Процес формування пошуково-дослідницьких умінь здобувачів вищої освіти є системним, комплексним процесом й реалізується у продовж всього періоду навчання студентів у закладі вищої освіти. Зважаючи на те, що майбутнім педагогам доведеться працювати в швидкозмінних умовах, тематика пошуково-дослідницьких проєктів спрямована на розв'язання актуальних проблем дошкільної та початкової освіти, покращення освітнього процесу у закладах дошкільної та загальної середньої освіти (початкова школа).

Варто зазначити, що розв'язання завдань пошуково-дослідницького проєкту розпочинається вже на етапі планування вибору проблематики й формулювання 
теми проєкту. Першорядним є педагогічний супровід, під яким вбачаємо, взаємопов'язану систему заходів та стимулів, що спрямовані на розв’язання дослідницьких завдань у перебігу виконання магістерського проєкту. Педагогічний супровід здійснюється науковим керівником на всіх етапах виконання студентами магістерського проєкту.

На першому етапі роботи над проєктом важливо з’ясувати актуальні питання дошкільної та початкової освіти, вивчити потреби педагогів-практиків. Оскільки саме від запитів закладів дошкільної, загальної середньої освіти буде залежати форма кінцевого освітнього продукту (інформаційний ресурс, що представлений у формі сайту, блогу, електронного посібника, каталогу авторських дидактичних ігор, методичного кейсу, рекомендацій тощо). Так, схвальні відгуки від педагогів закладів дошкільної освіти та початкових шкіл отримали такі студентські проєкти як: «Історія дошкільної освітим. Києва в педагогічних портретах» (автор: К. Степаненко), «Педагогічні персоналії на тлі епох» (автори: М. Башта, С. Кірілішина, Д. Музичук, Л. Потапенко, М. Ткач), «Гортаючи сторінки часопису «Світло») (автор: М. Свяженіна), «Путівник за ідеями Софії Русової: формування базових якостей дітей дошкільного віку» (автор: М. Ткач), «Поспішаймо робити добро» (автор: А. Колчіна), «Вивчаємо математику з героями улюблених казок» (автор: I. Кочерга) та ін.

Важливою умовою формування пошуково-дослідницьких умінь на цьому етапі є залучення студентів до теоретичного аналізу першоджерел, наративних матеріалів, документів про освіту (закони, постанови, положення, звіти тощо), що зберігаються у фондах Державної науково-педагогічної бібліотеки України імені В.О. Сухомлинського, Педагогічного музею України, Державному архіві м. Києва, Центральному державному архіві вищих органів влади та управління України. Саме на цьому етапі відбувається засвоєння студентами специфіки організації і проведення теоретичного дослідження, удосконалюються вміння здійснювати аналіз, синтез отриманих знань, зіставляти, узагальнювати, систематизувати джерела, моделювати процеси i явища, створювати бібліографічний опис. 
На другому етапі - відбувається розроблення алгоритму розв'язання пошуково-дослідницьких завдань магістерського проєкту. 3 цією метою студенти створюють індивідуальний план дослідження, вивчають стан розробленості досліджуваної проблеми у педагогічній практиці, роблять узагальнення та висновки, що складають основу для розроблення і впровадження в практику авторського освітнього продукту. Реалізація означених завдань можлива за умови сформованості у студентів таких компонентів пошуководослідницьких умінь, як: уміння планувати етапи проведення дослідження, робити відбір та застосовувати діагностичний інструментарій для збору емпіричних даних, узагальнювати та інтерпретувати отримані результати. Варто зауважити, що пошуково-дослідницькі уміння формують дослідницьку культуру, яка $є$ важливою для особистісного і професійного зростання майбутніх педагогів.

Наведемо приклад алгоритму розв'язання пошуково-дослідницьких завдань, що виконувалися під час розроблення проєкту, що був зреалізований у формі електронного посібника «Вивчаємо математику з героями улюблених казок» (автор: І. Кочерга). Створенню електронного посібника передувало дослідження, що було проведене студенткою на базі закладу загальної середньої освіти (початкова школа). У перебігу дослідження був зібраний емпіричний матеріал щодо з'ясування особливостей формування математичної компетентності учнів початкової школи, вивчено форми, методи та засоби, яким надають перевагу вчителі у формуванні означеної компетентності, визначено критерії, рівні та показники іiі сформованості в учнів початкової школи. Досліджено потреби вчителів у змістовому-методичному забезпеченні, що сприятиме реалізації завдань з формування математичної компетентності учнів початкової школі. Узагальнення результатів дослідження сприяли розробленню електронного посібника «Вивчаємо математику з героями улюблених казок» (рис. 1.). 

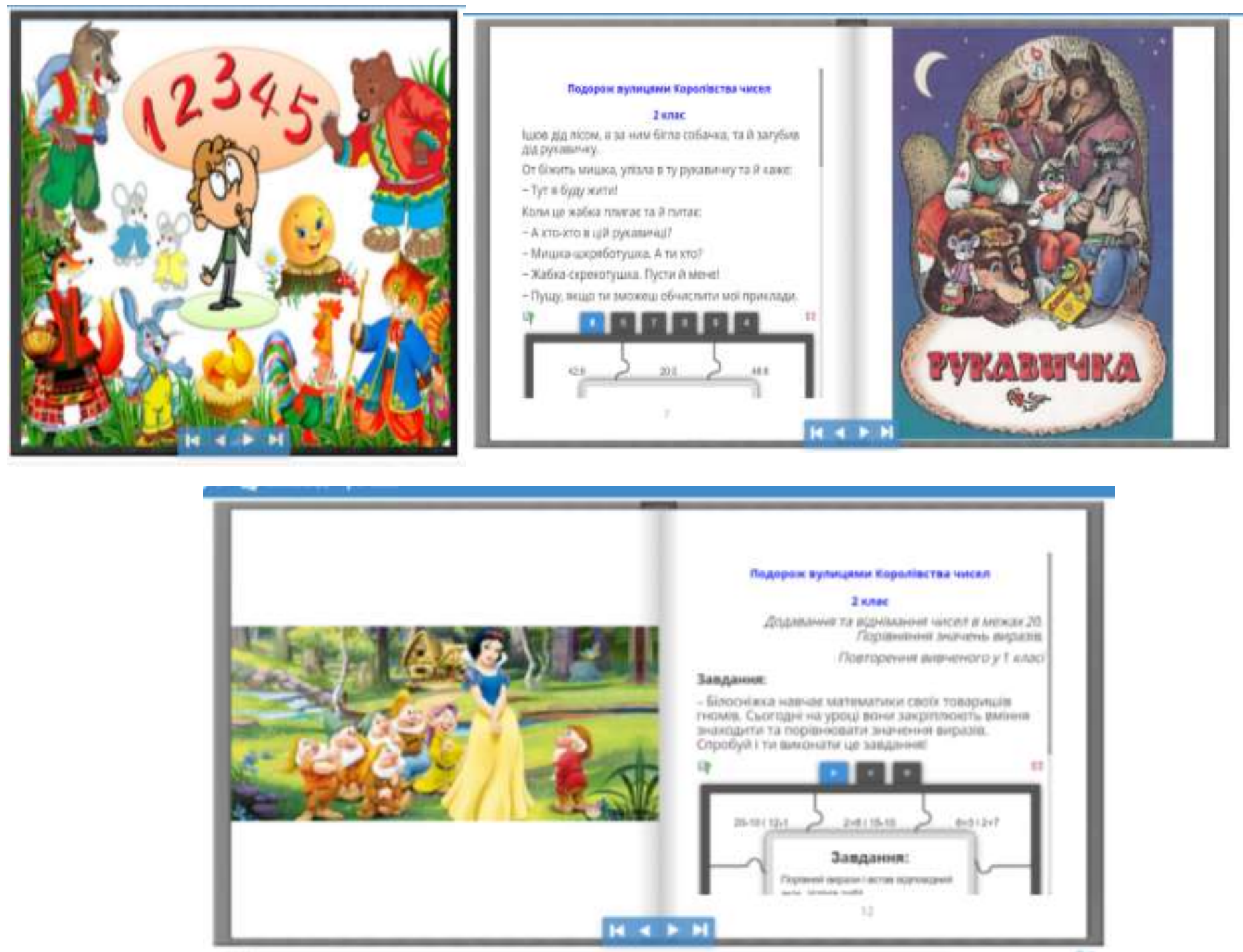

Рис. 1. Сторінки електронного посібника «Вивчаємо математику з героями улюблених казок» (автор: І. Кочерга)

Вивчення стану проблеми у практиці початкових шкіл сприяло удосконаленню умінь майбутніх педагогів розробляти стратегію ефективного вирішення дослідницького завдання, створювати й презентувати власні освітні продукти, продукувати нові знання задля їх використання у власній професійній діяльності.

На третьому етапі реалізації дослідницьких завдань відбувається апробація та впровадження створених освітніх продуктів. У перебігу впровадження проєкту в освітню практику здобувачі вищої освіти другого (магістерського) рівня вищої освіти мають можливість продемонструвати сформованість таких пошуково-дослідницьких умінь, як: уміння приймати виклики, що пов'язані із 
апробацією і впровадженням результатів дослідження, організовувати роботу команди задля ефективного впровадження проєкту, здійснювати рефлексію щодо визначення позитивних сторін результатів виконаного проєкту та окреслення питань, що потребують доопрацювання.

Варто зауважити, що окрім впровадження результатів проєктів у практику закладів освіти майбутні педагоги мають можливість їх презентувати публічно у формі виступів під час сесій історико-педагогічних студій, на всеукраїнських студентських науково-практичних конференціях, семінарах, круглих столах, педагогічних читаннях.

Позитивним $є$ те, що під час роботи над магістерським проєктом студенти мають можливість вивчати потреби педагогів-практиків, втілювати їхні запити у практичних матеріалах, що сприяють організації освітнього процесу у закладах дошкільної та початкової освіти з урахуванням принципу варіативності. В свою чергу, педагоги-практики мають можливість в зручний спосіб ознайомитися 3 проєктами, оскільки вони розміщені у відкритому доступі на сторінці кафедри педагогіки та психології Педагогічного інституту Київського університету імені Бориса Грінченка https://pi.kubg.edu.ua/struktura/kafedry-instytutu/kafedrapedahohiky/naukova-robota/studentska-nauka.html\#naukovi-publikatsii-studentiv. Зворотній зв'язок, який отримують майбутні педагоги від вихователів та вчителів, сприяє підсиленню практичної значущості їхніх розробок.

У підсумку зазначимо, що в умовах реалізації нових стандартів дошкільної та початкової освіти зростає потреба у переорієнтації підготовки фахівців у практичну площину, врахування особистісних сенсів здобувачів вищої освіти (студентоцентризм), а також формування загальних та фахових компетентостей, що забезпечать майбутнім педагогам кар'єрний розвиток.

Заслуговує на увагу те, що результати магістерських кваліфікаційних робіт, що виконуються у формі проєктів, мають практичну значущість, оскільки зорієнтовані на забезпечення варіативності організації розвивальної діяльності дітей дошкільного та молодшого шкільного віку, практичні матеріали 
зорієнтовані на потреби та інтереси здобувачів освіти, що в повній мірі відповідає Концепції Нової української школи.

Практика формування пошуково-дослідницьких умінь майбутніх педагогів у перебігу виконання магістерських проєктів доводить, що означені уміння $\epsilon$ важливою складовою їхнього особистісно-професійного розвитку. 